\title{
Content and Retention of Provitamin A Carotenoids Following Ripening and Local Processing of Four Popular Musa Cultivars from Eastern Democratic Republic of Congo
}

\author{
Beatrice Nakhauka Ekesa ${ }^{1}$, Judith Kimiywe ${ }^{2}$, Inge Van den Bergh ${ }^{3}$, Guy Blomme ${ }^{4}$, \\ Claudie Dhuique-Mayer ${ }^{5} \&$ Mark Davey $^{6}$ \\ ${ }^{1}$ Bioversity International, Plot 106, Katalima Road, P.O. Box, 24384, Kampala, Uganda \\ ${ }^{2}$ Department of Food, Nutrition and Dietetics, Kenyatta University, P.O. Box 43844, Nairobi, Kenya \\ ${ }^{3}$ Bioversity International, Parc Scientifique Agropolis II 34397 Montpellier Cedex 5 France \\ ${ }^{4}$ Bioversity International, Plot 106, Katalima Road, P.O. Box 24384, Kampala \\ ${ }^{5}$ Centre de Coopération Internationale en Recherche Agronomique pour le Développement (CIRAD), Dept. \\ Persyst-UMR Qualisud TA B95/16 73 av. J.F Breton 34398 Montpellier cedex, France \\ ${ }^{6}$ Laboratory of Fruit Breeding and Biotechnology, Department of Biosystems, Katholieke University of Leuven \\ (KULeuven), de Croylaan 42, Heverlee, B-3000, Leuven, Belgium
}

Correspondence: Beatrice Nakhauka Ekesa, Bioversity International, Plot 106, Katalima Road, P.O. Box, 24384, Kampala, Uganda. E-mail: b.ekesa@cgiar.org

Received: October 26, 2012 Accepted: December 12, 2012 Online Published: December 18, 2012

doi:10.5539/sar.v2n2p60

URL: http://dx.doi.org/10.5539/sar.v2n2p60

\begin{abstract}
Changes in the concentrations and retention levels of total and individual provitamin A carotenoids (pVACs) during ripening and local processing of the four most popular Musa cultivars of Eastern Democratic Republic of Congo were established through HPLC analysis. The predominant pVACs were all trans $\beta$ - and $\alpha$-carotene, together constituting about $90 \%$ of total pVACs content in raw and processed Musa fruit pulp. The proportion of $\beta$ - and $\alpha$-carotene was not significantly different in the tested East African Highland Bananas (AAA-EAHB) ('Nshikazi' and 'Vulambya'); in the plantains ('Musilongo' and 'Musheba'), proportion of $\beta$-carotene was almost twice that of $\alpha$-carotene. An increase in total pVACs was observed during ripening, with highest levels at ripening stage 3 in all four cultivars. Total pVACs values were as high as $1081 \mu \mathrm{g} / 100 \mathrm{gfw}$ in 'Vulambya' and $1819 \mu \mathrm{g} / 100 \mathrm{gfw}$ in 'Musilongo'. Boiling of the AAA-EAHB and AAB-Plantains resulted to retention of between $40-90 \%$ and $>95 \%$ respectively. Plantains deep-fried in fully-refined palm oil and crude red palm oil for 2 minutes did not seem to lose any pVACs, the levels of total pVACs observed after frying were $100 \%$ of what was observed when the fruit was raw. Retinol Activity Equivalents (RAE), in boiled products varied between 22.3 and $173 \mathrm{RAE} \mu \mathrm{g} / 100 \mathrm{gfw}$, whereas deep fried products had $>190 \mathrm{RAE} \mu \mathrm{g} / 100 \mathrm{~g}$ edible portion. These results show that the tested AAA-EAHBs and the plantains could meet at least $14 \%$ and $30 \%$ of Vitamin A recommended dietary intakes respectively. The findings can therefore guide consumer consumption patterns to maximize vitamin A intake for improved health in these regions and also direct researchers in the selection of Musa cultivars to be incorporated within existing farming systems in the fight against vitamin A deficiency (VAD).
\end{abstract}

Keywords: banana, plantain, Vitamin A deficiency, Democratic Republic of Congo, $\beta$-carotene, $\alpha$-carotene

\section{Introduction}

Micronutrients are essential for the survival, growth and functioning of the human body (World Health Organisation-WHO, 2009). Apart from well-known roles in vision, vitamin A is also important for several other physiological processes including, foetal development, immune response, and growth (WHO, 2009). According to the $6^{\text {th }}$ Report on the World Nutrition Situation, about 163 million of children in developing countries display vitamin A deficiency (Note 1), with a prevalence of about 30\% (Sub-Committee on Nutrition-SCN, 2010). In the Democratic Republic of Congo (DRC) estimates determined the prevalence of vitamin A deficiency (VAD) to be between $42.2 \%$ and $61.1 \%$ of the population, based on WHO estimates and the United Nations Sub-Committee on Nutrition (UNSCN) respectively. According to the classification provided by the International vitamin A 
Consultative Group (known as the Annecy Accords), a prevalence of over 30\% of the population represents a situation of severe VAD (SCN, 2010). Therefore in DRC, VAD is clearly a major public health problem. Reports indicate that effective, culturally appropriate food-based strategies are very important for sustainable solutions to reduce VAD (Ayewole-Olusola \& Asagbra, 2003). In addition, these strategies should give power to individuals and households. They lead to enhanced family food production, wise food selection, appropriate preparation/cooking methods, simultaneous provision of multiple nutrients and an enhancement of cultural pride and identity (Englberger, Schierle, Marks, \& Fitzgerald, 2003a).

The majority of the people in Eastern DRC engage in small-scale agriculture where bananas and plantains (Musa spp.) predominate (Dowiya, Rweyemamu, \& Maerere, 2009). Banana and plantain fruits are second in importance as a source of calories after cassava in this region, with about $75 \%$ and $69 \%$ of households in South Kivu (SK) and North Kivu (NK) reporting having consumed Musa fruit in a 24-hour period (Ekesa et al, In press). Although some households reportedly consume bananas on a daily basis (10\%), the majority of the households in these regions consume bananas/plantains between 2 and 4 times per week (Ekesa et al., in press). Ekesa et al. (In press) also report that the most popular and preferred Musa cultivars in Eastern DRC have pulp color ranging from yellow in EAHB cultivars 'Vulambya' and 'Nshikazi' (genome composition AAA), to dark yellow/orange for the French plantain cultivars 'Musilongo' and 'Musheba'. The occurrence of naturally orange pulped banana and plantain cultivars indicates their importance as a potential source of dietary pVACs. Recent research has highlighted the importance of dark/yellow/orange-fleshy Musa fruit as a source of pVACs, with the best-performing cultivars capable of providing up to $50 \%$ of the total recommended dietary intakes (RDIs) for vitamin A in a single fruit (Davey, Van den Bergh, Markham, Swennen, \& Keulemans, 2009a; Englberger et al., 2003a). Therefore due to their widespread consumption, a wider and more sustained uptake and use of pVACs-rich Musa varieties may provide a significant long-term beneficial impact on the health and nutritional status of populations in these areas.

After harvest, most Musa fruits are stored for some time before being processed into various forms for consumption. During the storage period, besides fruit ripening, the pVACs contents have been reported to remain unaltered, increase or decrease but these changes appear to depend on the cultivar (Davey, Keulemans, \& Swennen, 2006; Ngoh-Newilah et al., 2009).

In Eastern DRC the most popular local processing method is simply boiling, generally without the peel, (Ekesa et al., in press). Other ingredients added during boiling can include beans (fresh), amaranth leaves and occasionally, local palm oil. Plantains are also used to prepare banana flour. In South Kivu, the banana flour would be mixed with cassava flour to make the porridge, which is a common weaning food. Finally, plantain cultivars are occasionally deep fried in the local palm oil and eaten as 'banana fries' (Ekesa et al., in press).

In this study we have analysed the levels of pVACs in fruit of the four most popular Musa cultivars consumed in Eastern DRC, with the aim of characterizing the impact of fruit ripening and processing on pVACs contents. This information can be used to determine the potential contribution of Musa fruit and foods to the daily vitamin A RDIs and to help guide consumer consumption patterns to maximize vitamin A intakes for improved health in these regions.

\section{Materials and Methods}

\subsection{Sample Collection}

Previous work has established that the four most popular Musa varieties consumed in Eastern DRC are the EAHB cultivars 'Vulambya' (AAA) and 'Nshikazi' (AAA), and the plantain varieties 'Musilongo' (AAB) and 'Musheba' (AAB) (Ekesa et al., 2011). Only one mature disease-free plant/tree of each of these Musa cultivars was identified in farmer fields and marked by qualified agronomists from Beni (NK) and Bukavu (SK) territories using the botanical characteristics found in Table 1. When the fruits of the identified bunch for each cultivar were mature (deep green, full and rounded), or ripening stage 1 according to Dadzie and Orchard (1997), the bunch was harvested and two middle hands ( $2^{\text {nd }}$ and $3^{\text {rd }}$ hand), each containing between 12-16 fingers, were sampled and labelled according to cultivar. The samples from Beni territory (North Kivu) were packed in an aerated carton and transported as hand-luggage by air to Kampala the morning of the harvest, while the samples from Bukavu were also packed in an aerated carton and transported as hand-luggage by an overnight bus to Kampala. Samples from both sites arrived at the laboratory in Kampala within 48 hours of harvest. The ripening stages were estimated based on the peel color: $1=$ green; 2 = green with trace of yellow; $3=$ more green than yellow; 4 $=$ more yellow than green; $5=$ only green tips remaining; $6=$ all yellow; $7=$ yellow flecked with brown (Stover $\&$ Simmonds, 1987). The ripening stages used in this study were stages $1,3,5$ and 7 . 
Table 1. Description and botanic characteristics used in identification of the popular cultivars from Beni territory (North Kivu) and Bukavu territory (South Kivu), Eastern DRC

\begin{tabular}{|c|c|c|c|c|c|c|c|c|c|}
\hline \multirow[t]{2}{*}{ Local name } & \multirow[t]{2}{*}{ eOrigin } & \multirow[t]{2}{*}{ Synonyms } & \multirow{2}{*}{$\begin{array}{l}\text { Genomic } \\
\text { group }\end{array}$} & \multirow[t]{2}{*}{ Sub-group } & \multicolumn{5}{|c|}{ Botanic characteristic used to identify the cultivar } \\
\hline & & & & & Pseudostem & leaves & Bunch & Fruit & Male bud \\
\hline Vulambya & $\begin{array}{l}\text { Beni } \\
(\mathrm{DRC})\end{array}$ & $\begin{array}{l}\text { Malambya }^{2}, \\
\text { Bulambya }^{2}, \\
\text { Nyalambya }^{2}, \\
\text { Nyalambi }^{2} \text { (Rukonjo } \\
\text { (Uganda) }^{3}\end{array}$ & AAA-EA ${ }^{2,}$ & Lujugira-Mutika ${ }^{2}$ & $\begin{array}{l}{ }^{2} \geq 3 \text { metres } \\
\text { light green } \\
\text { with black } \\
\text { blotches }^{2}\end{array}$ & $\begin{array}{l}\text { Dirty } \\
\text { green }^{2}\end{array}$ & $\begin{array}{l}\text { Hangs } \\
\text { vertically, } \\
\text { Compact, } \\
\text { cylindrical, } \\
\text { maximum } 11 \\
\text { hands }^{2}\end{array}$ & $\begin{array}{l}\text { Straight, } \\
\text { Medium } \\
(15 \mathrm{~cm}-20 \mathrm{~cm} \\
\text { long), pointed } \\
\text { tips, maximum } \\
18 \text { fruits in } 3 \mathrm{rd} \\
\text { hand, naked } \\
\text { tips }^{2}\end{array}$ & $\begin{array}{l}\text { Ovoid } \\
\text { shaped, at } \\
\text { harvest about } \\
23 \mathrm{~cm} \text { width } \\
\text { and } 36 \mathrm{~cm} \\
\text { length, white } \\
\text { male flower }\end{array}$ \\
\hline Musilongo & $\begin{array}{l}\text { Beni } \\
(\mathrm{DRC})\end{array}$ & $\begin{array}{l}\text { Kasilongo }^{2}, \text { Munzabo }^{2} \\
\text { Kibeda }\end{array}$ & ${ }^{2} \mathrm{AAB}^{2,4}$ & $\begin{array}{l}\text { Plantain } \\
(\text { French horn })^{2}\end{array}$ & $\begin{array}{l}\geq 3 \text { metres } \\
\text { Red-purple }^{2}\end{array}$ & $\begin{array}{l}\text { Medium } \\
\text { green }^{2},\end{array}$ & $\begin{array}{l}\text { Hangs } \\
\text { vertically, Lax, } \\
\text { asymmetrical, } \\
\text { maximum } \\
\text { number of } \\
\text { hands } 9^{2}\end{array}$ & $\begin{array}{l}\text { Sharp curved } \\
\text { long fruit, } \\
\text { pointed tip } \\
\text { about } 14 \text { fruits } \\
\text { in 3rd hand, } \\
\text { persistent floral } \\
\text { remains on fruit } \\
\text { tips }^{2}\end{array}$ & $\begin{array}{l}\text { Lanceolate } \\
\text { shaped, } \\
\text { yellow male } \\
\text { flower }^{2}\end{array}$ \\
\hline Nshikazi & $\begin{array}{l}\text { Bukavu } \\
\text { (DRC) }\end{array}$ & $\begin{array}{l}\text { 'Magizi'= "bitter" }{ }^{3} \\
\text { Ishika'(Rwanda), }{ }^{3} \\
\text { Ensika',(Ug) } \\
\text { 'Emburansika' } \\
\text { Omuburasika'(Ug) }\end{array}$ & $\mathrm{AAA}-\mathrm{EA}^{4}$ & Lujugira-Mutika & $\begin{array}{l}\geq 3 \text { metres } \\
\text { light green } \\
\text { with black } \\
\text { blotches }{ }^{2}\end{array}$ & $\begin{array}{l}\text { Dirty } \\
\text { green }^{2}\end{array}$ & $\begin{array}{l}\text { Oblique and } \\
\text { compact } \\
\text { cylindrical } \\
\text { bunch }^{2}\end{array}$ & $\begin{array}{l}\text { Fruits medium } \\
\text { and pulp } \\
\text { astringent }^{2}\end{array}$ & $\begin{array}{l}\text { Ovoid } \\
\text { shaped, at } \\
\text { harvest about } \\
23 \mathrm{~cm} \text { width } \\
\text { and } 36 \mathrm{~cm} \\
\text { length, white } \\
\text { male flower }\end{array}$ \\
\hline Musheba & $\begin{array}{l}\text { Bukavu } \\
\text { (DRC) }\end{array}$ & $\begin{array}{l}\text { Busheba }^{3} \\
\text { misheba }^{3}\end{array}$ & $\mathrm{AAB}^{4}$ & $\begin{array}{l}\text { Plantain } \\
\text { (French) }\end{array}$ & $\begin{array}{l}\geq 3 \text { metres } \\
\text { Light green, } \\
\text { almost } \\
\text { yellowish }{ }^{2}\end{array}$ & $\begin{array}{l}\text { Medium } \\
\text { green }^{2}\end{array}$ & $\begin{array}{l}\text { Hangs } \\
\text { vertically, lax, } \\
\text { slightly } \\
\text { truncated cone } \\
\text { shape }^{2}\end{array}$ & $\begin{array}{l}\text { Fruits almost } \\
\text { straight and a bit } \\
\text { inflated. } \\
\text { Slightly pointed } \\
\text { tips with } \\
\text { persistent old } \\
\text { style }^{2}\end{array}$ & $\begin{array}{l}\text { Male bud } \\
\text { tlarge, red } \\
\text { purple and } \\
\text { persistent, } \\
\text { yellow male } \\
\text { flower }\end{array}$ \\
\hline
\end{tabular}

${ }^{2}=$ Universite Catholique de Graben (UCG) Butembo colection; ${ }^{3}=$ Unpublished reports/personal communication;

${ }^{4}=$ Simmonds \& Shepherd, (1995).

\subsection{Sample Preparation}

On arrival at the laboratory in Kampala, the fingers from each hand were detached from the hand, randomised/pooled together per cultivar. The pooled group, consisting of between 24 and 36 fingers, was randomly separated into 2 groups, one group being left to ripen naturally and another group being processed into different Musa products.

Samples ripening: The pooled and labelled Musa fruits were left in a well-aerated room to ripen naturally. Sub-samples consisting of two fingers were randomly selected at ripening stages stage 1, 3, 5 and 7 for each cultivar except 'Musilongo', which was already at ripening stage 2 on arrival at the laboratory. At each ripening stage, fruits were cleaned, peeled, quartered and the quarters of each finger placed in labelled zip-lock plastic bags, the air removed manually and stored at $-20^{\circ} \mathrm{C}$ until lyophilisation (maximum 2 weeks).

Samples processing: After obtaining the necessary ingredients from local markets, fruit from the four cultivars was processed into the most common Musa products/dishes as described in Table 2. The preparation methods tested included boiling, deep frying and processing into flour. All samples were processed at ripening stages 3 and 5 , and $\sim 100 \mathrm{gfw}$ aliquots of the processed samples put in labelled zip-lock plastic bags, the air removed 
manually and stored in a freezer at $-20^{\circ} \mathrm{C}$ before lyophilisation.

Table 2. Ingredients used and procedures followed in preparation and processing/cooking of the Musa products

\begin{tabular}{|c|c|c|c|}
\hline Musa product & Ingredients & Cooking procedure & Comments \\
\hline $\begin{array}{l}\text { Boiled Musilongo/ } \\
\text { Musheba in-peel }\end{array}$ & $\begin{array}{l}3 \text { fingers of plantain } \\
\text { (with peel) } \\
\text { (Musilongo / } \\
\text { Musheba) } 480 \mathrm{~g} \\
300 \mathrm{ml} \text { water }\end{array}$ & $\begin{array}{l}\text { Musilongo/Musheba fingers were cleaned, weighed and places in an } \\
\text { aluminium saucepan, about } 300 \mathrm{ml} \text { of water was added to submerge the } \\
\text { plantain fingers. These were boiled covered at medium heat for about } \\
20 \text { minutes. The remaining water was drained; the food was cooled } \\
\text { with the lid on. The boiled fruits were then hand peeled, weighed and } \\
\text { placed in labelled zip-locked plastic bags with air removed manually } \\
\text { and stored at }-20^{\circ} \mathrm{C} \text {. }\end{array}$ & $\begin{array}{l}\text { The two varieties } \\
\text { were cooked in } \\
\text { separate } \\
\text { saucepans }\end{array}$ \\
\hline $\begin{array}{l}\text { Boiled Musilongo/ } \\
\text { 2. Musheba without peel }\end{array}$ & $\begin{array}{l}3 \text { fingers of hand } \\
\text { peeled plantain } \\
\text { (Musilongo/Musheba) } \\
340 \mathrm{~g}, 300 \mathrm{ml} \text { water }\end{array}$ & $\begin{array}{l}\text { Musilongo/Musheba fingers were cleaned, hand peeled, weighed and } \\
\text { places in an aluminium sauce pan, and about } 300 \mathrm{ml} \text { of water was } \\
\text { added to just submerge the fruits. These were boiled covered at } \\
\text { medium heat for about } 15 \text { minutes. When cooked the remaining water } \\
\text { was drained, the food cooled with the lid on. The fingers were then } \\
\text { re-weighed, placed in labelled zip-lock plastic bags, air removed } \\
\text { manually, stored at }-20^{\circ} \mathrm{C} \text {. }\end{array}$ & $\begin{array}{l}\text { The two varieties } \\
\text { were cooked in } \\
\text { separate } \\
\text { saucepans }\end{array}$ \\
\hline Musilongo flour & $\begin{array}{l}\text { Unripe Musilongo } \\
\text { fingers }\end{array}$ & $\begin{array}{l}\text { Mature unripe Musilongo fingers were peeled using a knife, put in } \\
\text { polythene bags which were closed tightly and left to ferment for } 3 \\
\text { days. The mould was scrapped off the finger using a knife and the } \\
\text { bananas were put under the sun for } 1-2 \text { days to dry. Once dry, they } \\
\text { were crushed into small pieces and ground into flour using a local } \\
\text { grinding mill. }\end{array}$ & \\
\hline Musheba flour & $\begin{array}{l}\text { Unripe Musheba } \\
\text { fingers }\end{array}$ & $\begin{array}{l}\text { Mature unripe Musheba fingers were peeled using a knife, chopped } \\
\text { into uneven pieces about } 3 \text { inches, put on a laid out polythene bag } \\
\text { under the sun to dry (about } 2 \text { days). The dry pieces were crashed } \\
\text { further and ground into flour using a local grinding mill. }\end{array}$ & \\
\hline $\begin{array}{c}\text { Boiled } \\
\text { Vulambya/Nshikazi } \\
\text { in-peel }\end{array}$ & $\begin{array}{c}3 \text { fingers of } \\
\text { AAA-EAHB } \\
\text { (Vulambya/Nshikazi) } \\
\text { with peel } 360 \mathrm{~g} \\
\text { 300ml water }\end{array}$ & $\begin{array}{l}\text { The Vulambya/Nshikazi fingers were cleaned weighed and put in an } \\
\text { aluminium sauce pan, about } 300 \mathrm{ml} \text { water was added to just submerge } \\
\text { the bananas and covered with a tight lid and let to boil for } 15 \text { minutes } \\
\text { under medium heat. When cooked, the remaining water was drained } \\
\text { and the bananas were left to cool with the lid still on. After cooling, } \\
\text { they were weighed, hand peeled, re-weighed and put in labelled } \\
\text { zip-lock plastic bags with air removed manually and stored in dark } \\
\text { room at } 20^{\circ} \mathrm{C} \text {. }\end{array}$ & $\begin{array}{c}\text { Each of the } \\
\text { AAA-EAHB } \\
\text { cultivars was } \\
\text { boiled in a } \\
\text { separate sauce pan }\end{array}$ \\
\hline $\begin{array}{c}\text { Boiled } \\
\text { Vulambya/Nshikazi } \\
\text { without peel }\end{array}$ & $\begin{array}{c}3 \text { fingers of } \\
\text { AAA-EAHB (peeled } \\
\text { Vulambya) } \\
200 \mathrm{~g} 200 \mathrm{ml} \text { water, salt }\end{array}$ & $\begin{array}{l}\text { The Vulambya/Nshikazi fingers were carefully peeled with a knife, } \\
\text { cleaned, weighed and put in an aluminium sauce pan, } 200 \mathrm{ml} \text { water was } \\
\text { added, a pinch of salt added and covered with a tight lid and let to boil } \\
\text { for } 15 \text { minutes under medium heat. Excess water was drained, the } \\
\text { t bananas left to cool with the lid still on, re-weighed and put in labelled } \\
\text { zip-lock plastic bags with air removed manually and stored at } 20^{\circ} \mathrm{C} \text {. }\end{array}$ & $\begin{array}{l}\text { Each of the } \\
\text { AAA-EAHB } \\
\text { cultivars was } \\
\text { boiled in a } \\
\text { separate sauce pan }\end{array}$ \\
\hline $\begin{array}{l}\text { Musilongo/Musheba deep } \\
\text { fried in local palm oil \& } \\
\text { in cooking oil (Golden } \\
\text { fry) }\end{array}$ & $\begin{array}{l}3 \text { fingers of each } \\
\text { plantain cultivar } \\
\text { (stage } 5) \text { Local palm } \\
\text { oil/cooking oil, salt }\end{array}$ & $\begin{array}{l}\text { Plantains (Musilongo/Musheba) were cut off at both ends and hand } \\
\text { peeled. Sliced into } 1 / 4-1 / 2 \text { inch rounds, and weighed. In a large, heavy } \\
\text { saucepan, the local palm oil/cooking oil was heated over medium heat. } \\
\text { Once the oil sizzled when a slice of plantain was added, several } \\
\text { plantain slices were added and browned for about } 2 \text { minutes. They } \\
\text { were then transferred into a bowl to drain the excess oil and cool. They } \\
\text { were re-weighed, put in labelled zip-lock plastic bags with air removed } \\
\text { manually and stored at } 20^{\circ} \mathrm{C} \text {. }\end{array}$ & $\begin{array}{c}\text { Each variety of } \\
\text { the plantain was } \\
\text { deep fried } \\
\text { separately and } \\
\text { new oil was used. }\end{array}$ \\
\hline
\end{tabular}

All collected samples were then lyophilised for 72 hours, re-packaged in their labelled zip-lock plastic bags, air removed and stored in the dark for transport as hand luggage by air to the Laboratory of Fruit Breeding and Biotechnology, Department of Biosystems at the Catholic University of Leuven, Belgium for pVACs analysis. All quarantine requirements for transporting the samples were met. At the laboratory in Leuven, diagonally opposite quarters of the lyophilized fruit pulp were pooled and homogenized to a fine powder by grinding in a 
pestle and mortar in liquid nitrogen and later stored in sealed tubes in the dark at $-20^{\circ} \mathrm{C}$ until analysis.

\subsection{Extraction and Carotenoid Analysis}

\subsubsection{Chemicals and Solvents}

HPLC-grade tetrahydrofuran (THF) and tert-butyl methyl ether (t-BME) were obtained from Sigma Aldrich, (Bornem, Belgium), HPLC-grade methanol $(\mathrm{MeOH})$ from LabScan (Dublin, Ireland). Lutein, all-trans ß-carotene (t-BC), all-trans $\beta-8$-apocarotenal (apocarotenal), butylated hydroxytoluene (BHT), triethylamine and insoluble polyvinylpolypyrolidine (PVPP) were all obtained from Sigma-Aldrich.

\subsubsection{Extraction Method}

All extractions were carried out in triplicate according to procedures specifically developed for the analysis of Musa tissues. In brief, around $100 \mathrm{mg}$ aliquots of powdered lyophilised Musa fruit pulp were homogenised for 30 seconds at maximum speed with 3-5 glass beads in a 'FastPrep' reciprocal shaker in $400 \mu 1$ of ice-cooled extraction buffer. The extraction buffer consisted of THF:MeOH, 1:1 (v/v), containing $0.25 \%$ BHT and 2\% insoluble PVPP (Davey et al., 2009a: Davey et al., 2006). Following centrifugation (14,000 rpm for 20 min at $4^{\circ} \mathrm{C}$ ), the supernatant was transferred to a fresh micro-centrifuge tube and the pellet was re-extracted twice with $400 \mu 1$ of THF: $\mathrm{MeOH}, 1: 1(\mathrm{v} / \mathrm{v})$, containing $0.25 \%$ BHT without PVPP. Supernatants were collected and combined, and 8- apo $\beta$-carotenal at a final concentration of $0.002 \mu \mathrm{g} / \mathrm{ml}$ added as an internal standard.

\subsubsection{Carotenoid Analysis}

The combined supernatants were directly analysed by RP-HPLC using a Waters Alliance, 2690 Separations System fitted with an autosampler, thermostated at $8^{\circ} \mathrm{C}$, a pulse dampener and a $996 \mathrm{UV}$-Vis photodiode array detector (Waters, Massachusetts, USA). The entire system was controlled and the data were collected and integrated using the Millennium 4.0 software package. Extracts were resolved on a $150 \mathrm{x} 4.6 \mathrm{~mm}, \mathrm{YMC} \mathrm{C}_{30}$ $3-\mu \mathrm{m}$ particle size HPLC column (Achrom, Zulte, Belgium), using a 24 minute linear gradient of $2-50 \% \mathrm{t}-\mathrm{BME}$ in $\mathrm{MeOH}$ at $1.0 \mathrm{ml} / \mathrm{min}$ and regenerated with $95 \% \mathrm{t}-\mathrm{BME}$ in $\mathrm{MeOH}$. All buffers contained $0.05 \%$ BHT and $0.05 \%$ triethylamine. Peaks were quantified at $450 \mathrm{~nm}$ using a freshly-prepared standard curve in extraction buffer as described by Davey et al. (2006) and identified on the basis of their characteristic absorption spectra. Retention times relative to known standards were available (Davey et al., 2006; Azevedo-Meleiro \& Rodriguez-Amaya, 2004; Howe \& Tanumihardjo, 2006). Results were expressed as nmol pVACs/gdw. To obtain the equivalent fresh-matter pVACs values of the raw samples, the formula [fresh matter value $=$ value of dry matter/ (100/100-moisture \%)] was used.

\subsection{Assessment of Carotenoid Contents and Impact on Daily Vitamin a Recommended Dietary Intakes (RDIs)}

Different pVACs are converted in the body to vitamin A (retinol) with differing efficiencies. Therefore, to determine the relative vitamin A nutritional content of samples, total $\mathrm{pVACs}$ contents were first converted to all-trans b-carotene equivalents (t-BCEs) using the formula t-BCE $=0.5 \mathrm{t}-\mathrm{AC}+\mathrm{t}-\mathrm{BC}+0.53 \mathrm{c}-\mathrm{BC}$ ', where c-BC is the sum of 13-cis b-carotene and 13-cis a-carotene. These values were then converted into 'Retinol Activity Equivalents' (RAE) assuming that $1 / 12^{\text {th }}$ of the total t-BCEs ingested are taken up into the body (Yeum and Russell, 2002). The RAE in $\mu \mathrm{g} / 100 \mathrm{gfw}$ were compared to the vitamin A RDIs.

\subsection{Statistical Analysis}

Differences in mean values of provitamin A carotenoids observed following analysis of the different ripening stages and local processing methods were tested using analysis of variance (ANOVA) and determination of the significance of difference among samples using $p$-values obtained by post hoc tests of homogenous subsets, Duncan's Multiple Range Test (DMRT).

\section{Results and Discussion}

\subsection{Fruit Pulp Colour}

Pre-screening of fruit pulp colour of the Musa cultivars grown in Eastern DRC using the HarvestPlus carotenoid colour strip (Royal Horticultural Society, 2007) showed that of the four most popular Musa cultivars (two AAB-plantains and two AAA-EAHBs), the plantains varieties from both South Kivu and North Kivu had a dark yellow/orange pulp (RHS9/2 1355U, while the East African Highland banana (EAHB) cultivars varieties had a yellow pulp (RHS 3/1 107U).

\subsection{Changes in the pVACs During Ripening of Musa Fruit}

\subsubsection{Total Carotenoids and Total pVACs in the Four Musa Cultivars}

As previously observed by other researchers, the principal carotenoids identified in both the raw Musa fruits and 
the processed Musa fruits were t-BC, t-AC, and lutein, with minor amounts of the 13-cis isomers of $\mathrm{AC}$ and BC(Davey et al., 2009a; Englberger et al., 2003a; Ngoh-Newilah et al., 2009). Results of dry matter were converted into fresh weight by percentage of moisture content [(fresh sample weigh minus weight after lyophilisation) divide by fresh sample weight multiplied by 100)]. The mean total provitamin A carotenoids content of fruit calculated as the sum of the concentrations of t-AC, t-BC, cis-carotenoids (13-cis $\mathrm{BC}$ and 13-cis-AC) from each cultivar are summarized in Table 3. As shown, the total carotenoids contents ranged from 7.25 - $34.91 \mathrm{nmol} / \mathrm{g}(389.33-1874.67 \mu \mathrm{g} / 100 \mathrm{gfw})$ representing a 5 -fold variation. Mean total pVACs contents across and within the four cultivars varied 5-fold with the levels ranging from 7.07-33.88nmol/gfw (379.43$1819.38 \mu \mathrm{g} / 100 \mathrm{gfw})$ and an overall mean of $17.51 \mathrm{nmol} / \mathrm{gfw}(940.04 \mu \mathrm{g} / 100 \mathrm{gfw})$. These observed values were significantly different if compared to about $8,000 \mu \mathrm{g} / 100 \mathrm{gfw}$ observed in sweet potato (Davey et al., 2009).

Table 3. Content of t-BC, t-AC and total pVACs in the four Musa cultivars tested in nmol/gfm. Values are means of three independent sub-samples per ripening stage per cultivar

Table 3a. Musilongo AAB plantain

\begin{tabular}{cccc}
\hline Ripening stage & t-AC(SD) & t-BC(SD) & Total pVACs \\
\hline 2 & $9.38(1.05)^{\mathrm{c}}$ & $17.76(0.37)^{\mathrm{c}}$ & $27.31^{\mathrm{c}}$ \\
3 & $11.13(2.10)^{\mathrm{d}}$ & $22.57(0.01)^{\mathrm{d}}$ & $33.88^{\mathrm{d}}$ \\
5 & $8.17(1.20)^{\mathrm{a}}$ & $15.44(0.29)^{\mathrm{a}}$ & $23.73^{\mathrm{a}}$ \\
7 & $9.00(0.03)^{\mathrm{b}}$ & $17.04(1.07)^{\mathrm{b}}$ & $26.22^{\mathrm{b}}$ \\
p- Value & $<0.001$ & $<0.001$ & $<0.001$ \\
\hline
\end{tabular}

Means in the same column with the same letter are not significantly different.

Table 3b. Musheba AAB

\begin{tabular}{cccc}
\hline Ripening stage & $\mathrm{t}-\mathrm{AC}(\mathrm{SD})$ & $\mathrm{t}-\mathrm{BC}(\mathrm{SD})$ & Total pVACs \\
\hline 1 & $2.360 .42)^{\mathrm{a}}$ & $4.71(0.82)^{\mathrm{a}}$ & $7.07^{\mathrm{a}}$ \\
3 & $6.74(1.06)^{\mathrm{d}}$ & $15.51(1.05)^{\mathrm{d}}$ & $22.55^{\mathrm{d}}$ \\
5 & $5.63(0.04)^{\mathrm{c}}$ & $11.94(0.03)^{\mathrm{c}}$ & $17.80^{\mathrm{c}}$ \\
7 & $4.39(0.11)^{\mathrm{b}}$ & $7.09(1.22)^{\mathrm{b}}$ & $11.53^{\mathrm{b}}$ \\
p-Value & $<0.001$ & $<0.001$ & $<0.001$
\end{tabular}

Means in the same column with the same letter are not significantly different.

Table 3c. Vulambya AAA-EAHB

\begin{tabular}{cccc}
\hline Ripening stage & $\mathrm{t}-\mathrm{AC}(\mathrm{SD})$ & $\mathrm{t}-\mathrm{BC}(\mathrm{SD})$ & Total pVACs \\
\hline 1 & $5.50(0.09)^{\mathrm{a}}$ & $4.71(0.06)^{\mathrm{a}}$ & $10.31^{\mathrm{a}}$ \\
3 & $10.48(0.68)^{\mathrm{d}}$ & $9.39(1.03)^{\mathrm{d}}$ & $20.13^{\mathrm{d}}$ \\
5 & $9.58(0.38)^{\mathrm{c}}$ & $7.81(1.28)^{\mathrm{c}}$ & $17.61^{\mathrm{c}}$ \\
7 & $8.86(0.08)^{\mathrm{b}}$ & $7.50(0.10)^{\mathrm{b}}$ & $16.63^{\mathrm{b}}$ \\
p-Value & $<0.001$ & $<0.001$ & $<0.001$ \\
\hline
\end{tabular}

Means in the same column with the same letter are not significantly different.

Table 3d. Nshikazi AAA-EAHB

\begin{tabular}{cccc}
\hline Ripening stage & $\mathrm{t}-\mathrm{AC}(\mathrm{SD})$ & $\mathrm{t}-\mathrm{BC}(\mathrm{SD})$ & Total pVACs \\
\hline 1 & $5.28(1.10)^{\mathrm{b}}$ & $4.31(1.07)^{\mathrm{b}}$ & $9.67^{\mathrm{b}}$ \\
3 & $6.47(0.02)^{\mathrm{c}}$ & $7.32(1.21)^{\mathrm{c}}$ & $13.70^{\mathrm{c}}$ \\
5 & $3.77(0.21)^{\mathrm{a}}$ & $3.60(0.92)^{\mathrm{a}}$ & $7.77^{\mathrm{a}}$ \\
7 & $6.36(1.02)^{\mathrm{c}}$ & $6.83(0.61)^{\mathrm{c}}$ & $14.16^{\mathrm{c}}$ \\
$\mathrm{p}$-Value & $<0.001$ & $<0.001$ & $<0.001$ \\
\hline
\end{tabular}

Means in the same column with same letter are not significantly different. 
The results show that there are statistically significant differences in the fruit mean total pVACs contents at each stage of post-harvest ripening, similar to results reported by Ngoh-Newila et al. (2008) working with Cameroonian Musa varieties. In 'Musheba', 'Musilongo', and 'Vulambya' the highest levels of t-BC, t-AC and total pVACs were observed at ripening stage 3 , and the difference observed as the fruit progressed in ripening was significant (Tables 3a, b, c). In 'Nshikazi' the highest levels were observed at ripening stages 3 and 7 but as indicated in Table $3 \mathrm{~d}$, the difference observed at stage 3 and 7 was not significantly different.

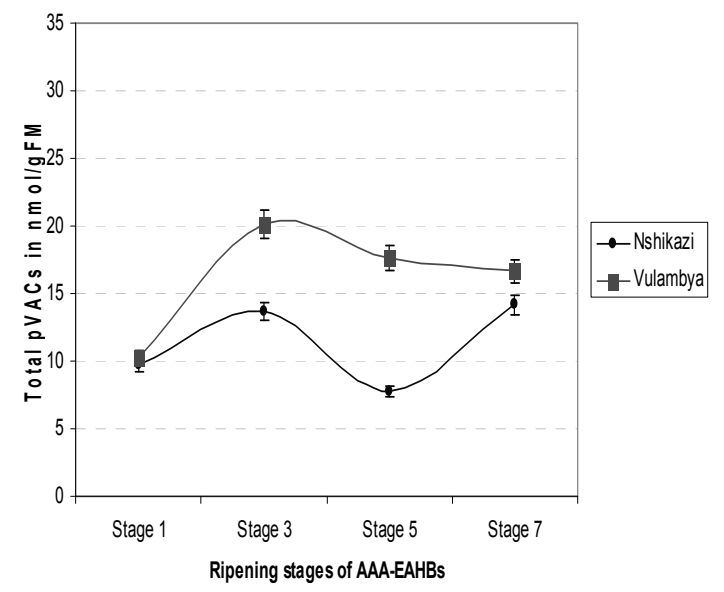

Figure 1a. Impact of fruit ripening on carotenoids in AAA-EAHB cultivars



Figure 1b. Impact of fruit ripening on carotenoids in ABB plantain cultivars

Figure 1. Changes in fruit total pVACs $t-A C,+t-B C+c$-carotenes during ripening of two popular AAA-EAHB and $\mathrm{AAB}$ plantain cultivars grown and consumed in Eastern Democratic Republic of Congo

A similar observation was made when 'Popoulou', a cooking banana grown and consumed in Cameroun, was tested. The levels of carotenoids in 'Popoulou' increased during the initial ripening stages and the highest levels recorded at ripening stage 3 (Ngoh-Newilah et al., 2008). In this study, as the fruits progressed from ripe to fully-ripe and then to over-ripe (ripening stages 3 to 7), each of the four cultivars showed a different trend and each of these changes was significant at a $\mathrm{p}$ value of 0.05 . What is also clear for all the cultivars is that, after beginning to ripen, the levels of total and specific carotenoids observed were higher that what was observed at ripening stage one. This could be because banana is a climacteric crop, and phytoene synthase, which controls the committed step of the carotenoid biosynthesis pathway, is induced by ethylene during fruit ripening (Van den Bergh \& Vezina, 2012). These findings also support reports that impact of ripening on pVACs is cultivar specific, and the pVACs contents can remain essentially unaltered, increasing or even slightly decreasing depending on the genotype (Van den Bergh \& Vezina, 2012). Another point to support the higher levels of pVACs observed when the fruit is ripe as compared to when the fruit is raw (stage 1) is that, fruit ripeness could influence the efficiencies of carotenoids extraction due to pulp softening and the breakdown of cellular structure in ripe fruit (Van den Bergh \& Vezina, 2012).

\subsubsection{Musa pVACs Profiles during Post-harvest Ripening}

Figure 2 shows that in all the four cultivars tested $\sim 90 \%$ of the total pVACs consisted of t-AC and t-BC alone, the remaining $10 \%$ comprised of their respective 13-cis-isomers. This is similar to observations made by Davey et al. (2009a), where a total of $171 \mathrm{Musa}$ cultivars were analysed for pVACs and invariably over $90 \%$ of the total pVACs consisted of only t-AC and t-BC. However, these results are quite different from the carotenoids profile reported for other crops such as maize and wheat where the pVACs only represent between $10-20 \%$ of the total carotenoid content. 


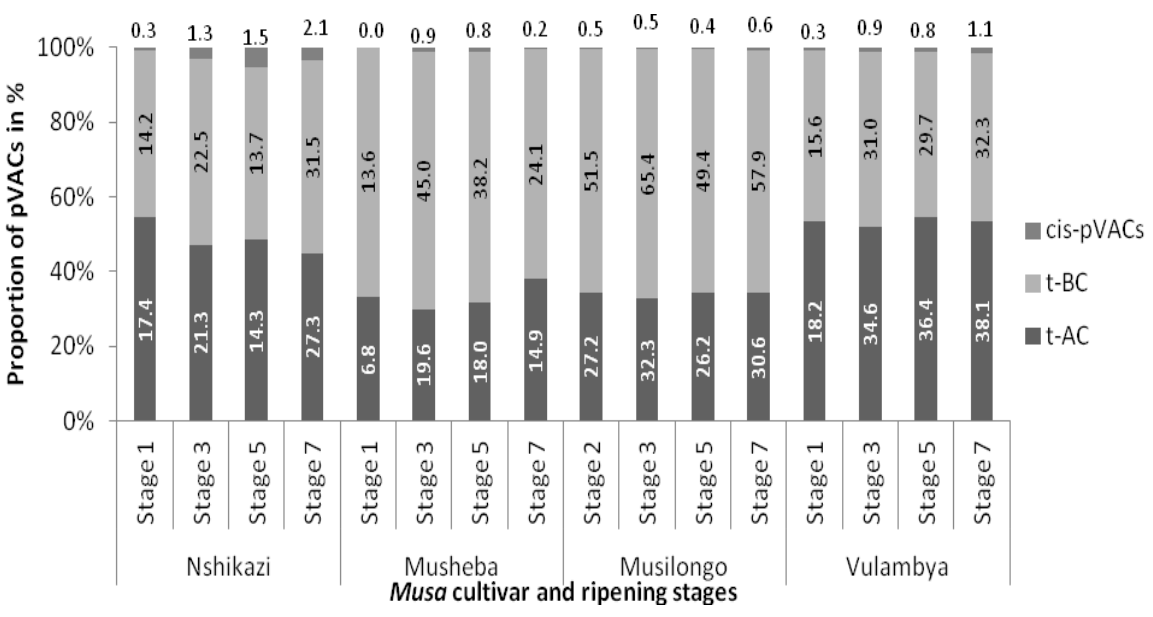

Figure 2. Overview of the variation in proportion of individual pVACs at different ripening stages within individual fruit of four Musa cultivars from Eastern DRC

The vitamin A nutritional value of banana and plantain fruits depends not only on the concentration of pVACs but also on the relative proportion of the individual pVACs present. This is because, from a nutritional viewpoint, fruit/foods with higher $\mathrm{t}-\mathrm{BC}$ contents are preferred as $\mathrm{t}-\mathrm{BC}$ is the $\mathrm{pVAC}$ with the highest vitamin A nutrition value. $\mathrm{t}-\mathrm{AC}$ has only $50 \%$ of the vitamin A activity of t-BC, thus the relative proportions of t-AC and $\mathrm{t}-\mathrm{BC}$ affect the overall vitamin A nutritional values of the fruit (Fraser \& Bramley, 2004; Trumbo, Yates, Schlicker-Renfro, \& Suitor, 2003).

In the two plantains tested ('Musheba' and 'Musilongo') the proportion of t-AC ranged from $30 \%$ to $38 \%$ while that of t-BC ranged from $61 \%$ to $69 \%$ indicating that the proportion of $\mathrm{t}-\mathrm{BC}$ is almost double that of $\mathrm{t}-\mathrm{AC}$. Among the East African Highland (EAHB) cultivars ('Vulambya' and 'Nshikazi'), the proportion of t-AC was slightly higher than that of $\mathrm{t}-\mathrm{BC}$ with that of $\mathrm{t}-\mathrm{AC}$ being between $44 \%$ to $54 \%$ and that of $\mathrm{t}-\mathrm{BC}$ being between $44 \%$ to $51 \%$, but these differences were not statistically significant (Figure 2).

\subsection{Changes and Retention of Pvacs in Musa Fruit during Processing}

Provitamin A carotenoids are known to be easily destroyed during processing, exposure to light and heat treatment. Studies to assess the net retention rate of pVACs from different processing techniques indicate that that prolonged exposure to heat treatments such as deep frying, boiling and a combination of several processing techniques can result in substantial losses (Ruel \& Howarth, 2004). However data documented so far are somehow conflicting and often difficult to interpret (Ngoh-Nweilah et al., 2008). The reason for the inconsistent results have been processing conditions are partially or not even described, different foods are processed differently in different settings, making consistent comparison difficult. Also, sometimes different conditions such as temperature and time are used in the same processing methods (Rodriguez-Amaya \& Kimura, 2004)

\subsubsection{Changes and Retention of pVACs during Boiling}

Fruit from all four cultivars at stage three of ripening were boiled either with or without their peel (Table 2). The content of total pVACs in the boiled plantains and AAA-EAHB cultivars ranged from $6.7-47.9 \mathrm{nmol} / \mathrm{gfw}$ (357.64-2570.08 $\mu \mathrm{g} / 100 \mathrm{gfw}$ ) edible portion. Among the AAA-EAHB cultivars ('Nshikazi' and 'Vulambya'), the total pVACs in the raw fruit was significantly higher in raw fruit compared to boiled fruit. Interestingly, in 'Nshikazi', $50 \%$ of the total pVACs were retained when the cultivar was boiled in-peel and only $39.7 \%$ retention when the cultivar was boiled without peel. By comparison, boiled 'Vulambya' retained $89.6 \%$ of the total pVACs contents in-peel and $65.4 \%$ when boiled without peel.

There was a retention of $>95 \%$ of total pVACs following boiling of the two plantains 'Musilongo' and 'Musheba'. In 'Musilongo', there was actually an increase in the total pVACs recovered following boiling (Table 4a, b, c, d). A study done on Banana cultivars from Cameroon also shown that the carotenoids were lost during boiling and the loss observed when the banana was boiled without peel $(30 \%)$ was higher than that observed when the same banana cultivars were boiled with the peel $(28 \%)$ although the observed difference was not statistically significant. This observed loss has been attributed to enzymatic or non-enzymatic oxidation and 
isomerisation of trans-carotenes to cis-isomers.

Table 4. Mean concentrations of all- trans b-carotene (t-BC), all-trans a-carotene ( $\mathrm{t}-\mathrm{AC})$ and total pVACs $(\mathrm{t}-\mathrm{AC}+$ $\mathrm{t}-\mathrm{BC}$ etc.), in fruit of raw and processed Musa cultivars. Values are means of three independent sub-samples per processing method/product per cultivar

Table 4a. Vulambya AAA-EAHB

\begin{tabular}{llll}
\hline & \multicolumn{4}{l}{ Provitamin A carotenoids in nmols/gfm } \\
\hline Processing method & t-AC(SD) & t-BC(SD) & Total pVACs \\
Raw & $10.48(0.68)^{\mathrm{c}}$ & $9.39(1.03)^{\mathrm{c}}$ & $20.13^{\mathrm{c}}$ \\
Boiled with peel & $8.09(1.40)^{\mathrm{b}}$ & $5.58(0.57)^{\mathrm{b}}$ & $13.67^{\mathrm{b}}$ \\
Boiled no peel & $5.65(2.43)^{\mathrm{a}}$ & $4.33(1.83)^{\mathrm{c}}$ & $9.98^{\mathrm{a}}$ \\
p- Values & $<0.001$ & $<0.001$ & $<0.001$ \\
\hline
\end{tabular}

Means in the same column with the same letter are not significantly different.

Table 4b. Nshikazi AAA-EAHB

\begin{tabular}{llll}
\hline & \multicolumn{3}{l}{ Provitamin A carotenoids in nmols/gfm } \\
\hline Processing method & t-AC(SD) & t-BC(SD) & Total pVACs \\
Raw & $6.47(0.02)^{\mathrm{c}}$ & $6.83(0.61)^{\mathrm{c}}$ & $13.69^{\mathrm{c}}$ \\
Boiled with peel & $4.07(1.07)^{\mathrm{b}}$ & $4.31(0.85)^{\mathrm{b}}$ & $8.38^{\mathrm{b}}$ \\
Boiled no peel $^{\mathrm{a}}$ & $3.41(0.10)^{\mathrm{a}}$ & $3.25(0.26)^{\mathrm{a}}$ & $6.67^{\mathrm{a}}$ \\
p- Values & $<0.001$ & $<0.001$ & $<0.001$ \\
\hline
\end{tabular}

Means in the same column with the same letter are not significantly different.

Table 4c. Musilongo AAB plantain

\begin{tabular}{llll}
\hline & \multicolumn{3}{l}{ Provitamin A carotenoids in nmols/gfm } \\
\hline Processing method & t-AC(SD) & t-BC(SD) & Total pVACs \\
Raw & $8.17(1.20)^{\mathrm{b}}$ & $15.44(0.29)^{\mathrm{b}}$ & $23.73^{\mathrm{b}}$ \\
Boiled with peel & $16.67(0.45)^{\mathrm{c}}$ & $22.87(0.88)^{\mathrm{c}}$ & $39.54^{\mathrm{c}}$ \\
Boiled no peel & $18.10(2.67)^{\mathrm{d}}$ & $29.76(5.66)^{\mathrm{d}}$ & $47.86^{\mathrm{d}}$ \\
Deep fried vegetable oil & $26.75(0.84)^{\mathrm{e}}$ & $43.57(1.28)^{\mathrm{e}}$ & $70.32^{\mathrm{e}}$ \\
Deep fried palm oil & $47.75(0.82)^{\mathrm{f}}$ & $82.79(1.95)^{\mathrm{f}}$ & $130.54^{\mathrm{f}}$ \\
Musilongo flour & $4.07(0.16)^{\mathrm{a}}$ & $6.18(0.83)^{\mathrm{a}}$ & $10.26^{\mathrm{a}}$ \\
p-Values & $<0.001$ & $<0.001$ & $<0.001$ \\
\hline
\end{tabular}

Means in the same column with the same letter are not significantly different.

Table 4d. Musheba AAB plantain

\begin{tabular}{llll}
\hline & \multicolumn{3}{l}{ Provitamin A carotenoids in nmols/gfm } \\
\hline Processing method & t-AC(SD) & t-BC(SD) & Total pVACs \\
Raw & $5.63(0.04)^{\mathrm{a}}$ & $11.94(0.03)^{\mathrm{b}}$ & $17.80^{\mathrm{b}}$ \\
Boiled with peel & $6.38(0.59)^{\mathrm{c}}$ & $7.62(0.94)^{\mathrm{a}}$ & $13.89^{\mathrm{a}}$ \\
Boiled no peel & $6.18(1.47)^{\mathrm{b}}$ & $7.71(1.87)^{\mathrm{a}}$ & $14.00^{\mathrm{a}}$ \\
Deep fried vegetable oil & $20.02(0.20)^{\mathrm{d}}$ & $31.24(0.15)^{\mathrm{c}}$ & $54.16^{\mathrm{c}}$ \\
Deep fried palm oil & $42.93(2.03)^{\mathrm{f}}$ & $84.42(3.66)^{\mathrm{e}}$ & $149.50^{\mathrm{e}}$ \\
Musheba flour & $37.24(0.48)^{\mathrm{e}}$ & $46.19(0.01)^{\mathrm{d}}$ & $83.42^{\mathrm{d}}$ \\
p-Values & $<0.001$ & $<0.001$ & $<0.001$ \\
\hline
\end{tabular}

Means in the same column with the same letter are not significantly different. 
The difference in the content of individual and total pVACs observed in the raw AAB plantains at ripening stage 5 and that observed following boiling at the same ripening stages was statistically significant (Table $4 \mathrm{c}$, d). Just as mentioned before and observed by Ngoh-Newilah (2007), the findings of this study indicate that there was slightly higher retention when the Musa fruit was boiled in-peel as compared to when boiled without peel, although the difference was not statistically significant. In addition, boiling of the two plantains led to a significantly higher retention level $(\mathrm{p}=0.05)$ as compared to when the two AAA-EAHB are boiled. This could possibly be due to the level at which the cellulose is broken down in the two different genotypes and the higher the breakdown level, the easier it is for the carotenoids to be extracted (Azizah, Wee, Azizah, \& Azizah, 2009). The AAA-EAHBs ('Nshikazi' and 'Vulambya) showed easy breakdown leaving the boiled banana very soft and mushy while the plantains ('Musheba' and 'Musilongo') kept their form, even after boiling.

\subsubsection{Changes and Retention of pVACs during Deep Frying}

In the two plantains ('Musilongo' and 'Musheba'), the content of total pVACs observed following deep frying in pure vegetable cooking oil 'Golden fry' for 2 minutes was significantly higher than that observed in the raw fruits (Table 4c, d). Although deep frying and especially for prolonged periods has been documented to result into substantial loss in pVACs (Rodriguez-Amaya, 1997). In this study, the reported higher levels of pVACs observed after deep frying can be supported by Rojaz-Gonzalez, Avallone, Brat, Trystram and Bohuon (2006). In addition, the deep frying for only 2 minutes can explain the difference, when these findings are compared to those of studies on orange fleshed sweet potato (OFSP), where lower levels of retention 76-80\% were reported following deep frying for 10 minutes (Bengtsson et al., 2008). Another reason could be that, in our study we used pure vegetable oil fortified with $2.06 \mathrm{mg} / 100 \mathrm{~g}$ of Retinol, in the OFSP study, sunflower oil containing insignificant carotenoids was used (Bengtsson et al., 2008). Therefore, although studies have indicated loss of pVACs following deep frying (Rodriguez-Amaya, 1997), more pVACs can be retained following reduction of frying time to 2 minutes or less. In addition, the increase could also be due to unaccounted loss of water, where the space previously occupied by water is replaced by oil during frying (Rodriguez-Amaya \& Kimura, 2004)

\subsubsection{Changes and Retention of pVACs during Processing Plantain into Flour}

Through comparison of the total pVACs in the raw Musa cultivars and the two plantain flours; 'Musilongo' and 'Musheba', a loss of about $98.3 \%$ of pVACs was recorded. This means that by the time this flour is being used in porridge or the local hard paste 'Ugali', almost all the carotenoids have been destroyed. As mentioned earlier, prolonged storage, exposure to sunlight and chopping into small pieces (and grinding into flour) leads to substantial loss in pVACs. As described in Table 2, processing 'Musilongo' into flour, involved peeling, chopping the bananas into small pieces fermenting for 2-3 days, direct sun-drying and grinding into flour. This process that takes at least a week and explains the very high loss of carotenoids observed. Contrary to the observations above, processing of 'Musheba' the plantain from South Kivu resulted into a loss of only 23\% of the total pVACs (Table 3c,d), this could be because when processing 'Musheba' into flour, some of the stages such as keeping in a warm place and allowing to ferment for 2-3 days did not take place and thus the process was shorter and less rigorous (Table 2).

\subsubsection{Impact of Processing on pVACs Profiles}

Figures 3 and 4 show the HPLC profiles of the carotenoids obtained after heat processing. Just as observed in the raw samples of the same four cultivars, the main carotenoids observed were t-AC and t-BC representing between $82 \%$ and $99 \%$ of the total carotenoids in 'Vulambya' and between $65 \%$ and $78 \%$ of total carotenoids in Nshikazi, depending on ripening stage. The difference in the proportion of the sum of main carotenoids in the two EAHB cultivars following boiling was statistically significant $(\mathrm{p}=0.0147)$. In the two EAHB products the proportion of $\mathrm{t}-\mathrm{AC}$ to t-BC was not statistically different. The proportion of Lutein was significantly higher in 'Nshikazi' as compared to 'Vulambya' $(\mathrm{p}=0.00956)$. The proportion of $\mathrm{t}-\mathrm{AC}$ to $\mathrm{t}-\mathrm{BC}$ in Musheba and Musilongo was statistically difference $(\mathrm{p}=0.0008)$ and $(\mathrm{p}=0.00023)$ respectively, with that of $\mathrm{t}-\mathrm{BC}$ almost double that of $\mathrm{t}-\mathrm{AC}$. The deep fried Musheba had some 13-cis-carotenoids indicating that cooking especially under high heat promotes formation of cis isomers, which have a lower vitamin A activity (Booth, Johns, \& Kuhunlein, 1992). 


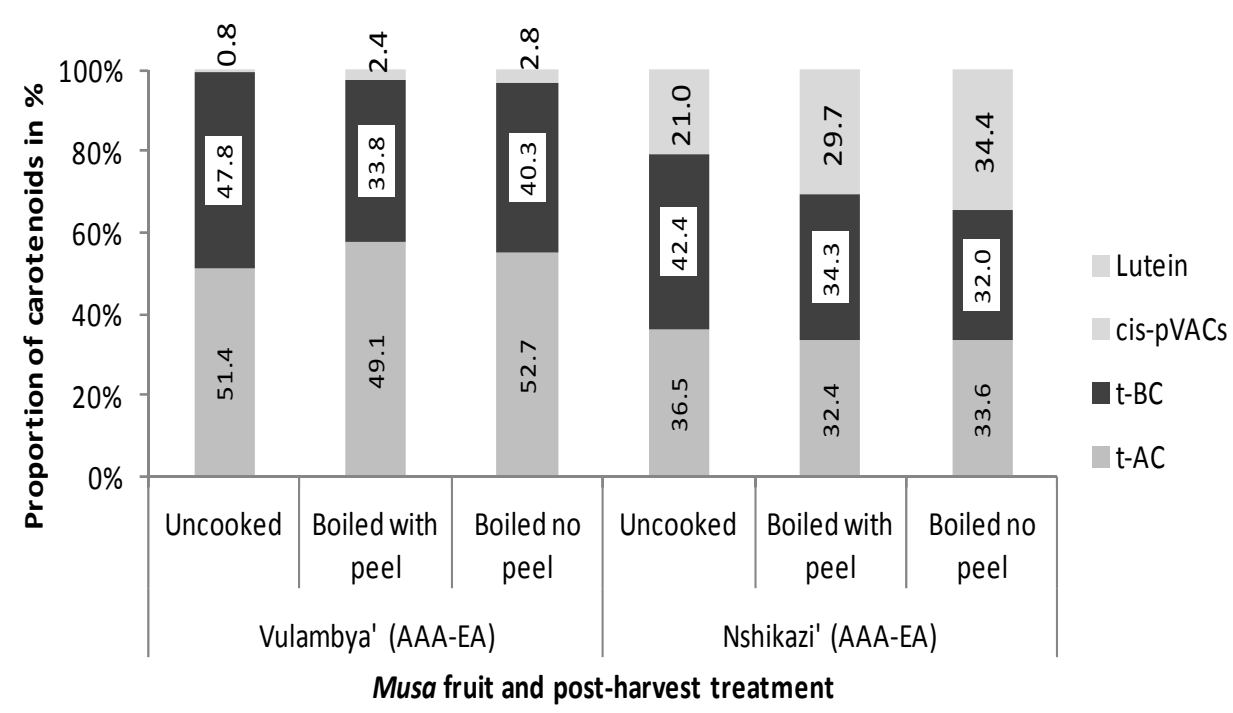

Figure 3. Overview of the variation in proportion of individual pVACs in boiled AAA-EAHB cultivars popular in Eastern Democratic Republic of Congo

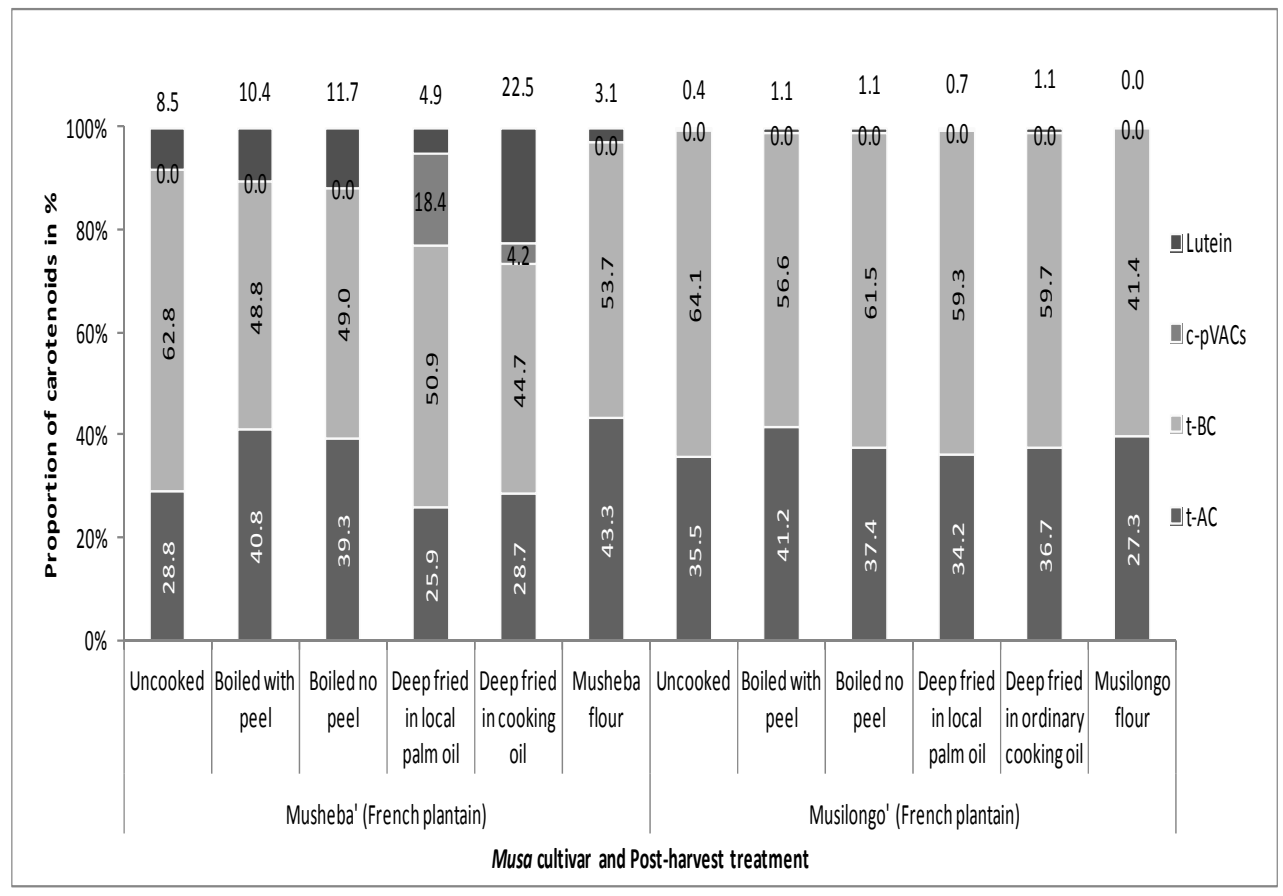

Figure 4. Overview of the variation in proportion of individual pVACs in heat processed (boiled and fried) plantain cultivars popular in Eastern Democratic Republic of Congo

\subsection{Impact of Raw and Processed Musa Fruit on Vitamin A Requirement of Children <5yrs and Women between $15-45 y r s$}

At the ripening stages at which the fruit are normally consumed, (stage 3 for AAA-EAHB, and stage 5 for plantains), RAE values ranged from 45.99 to $66.09 \mu \mathrm{g}$ RAE/100 gfw in 'Nshikazi', and 'Vulambya', and from 66.59 to $87.7 \mu \mathrm{g}$ RAE/100 gfw for 'Musheba' and 'Musilongo' respectively. In all four cultivars, the highest RAE values were measured at ripening stage 3 (Figure 1 and Table 3). In boiled Musa fruits RAE values ranged from 22.26 - $173.66 \mu \mathrm{gRAE} / 100 \mathrm{gfw}$ edible portion, while the RAE values in the plantains deep fried in local 
red palm oil were as high as $526.38 \mu \mathrm{gRAE} / 100 \mathrm{gfw}$ edible portion. According to Englberger et al. (2006a), Musa cultivars with RAE values more than 70 are considered good sources of vitamin A, therefore, the two plantains 'Musilongo' and 'Musheba' are good sources of vitamin A, while the two AAA-EAHB cultivars 'Nshikazi' and 'Vulambya' also possess significant levels of vitamin A.

Table 5. Beta carotene equivalent (BCE), Retinol activity equivalent (RAE) and $\%$ contribution to recommended dietary intakes(RDIs) of vitamin A for a child 1-5years consuming 200g (at least 2 fingers) of fruit and an adult woman consuming $500 \mathrm{~g}$ (at least 4 fingers) of fruit

\begin{tabular}{|c|c|c|c|c|c|c|c|}
\hline \multirow{2}{*}{$\begin{array}{l}\text { Local name } \\
\text { (Origin) }\end{array}$} & \multirow{2}{*}{$\begin{array}{l}\text { Ripening stages \& } \\
\text { processing style }\end{array}$} & \multirow{2}{*}{$\begin{array}{c}\text { Total } \\
\text { BCE } \\
\mu \mathrm{g} / 100 \mathrm{~g} \\
\text { FM }\end{array}$} & \multirow{2}{*}{$\begin{array}{l}\text { RAE in } \\
\mu \mathrm{g} / 100 \\
\mathrm{gFM}\end{array}$} & \multicolumn{2}{|c|}{$\begin{array}{c}\text { \% RDI child } \\
<5 \mathrm{yrs}\end{array}$} & \multicolumn{2}{|c|}{$\%$ RDIs woman } \\
\hline & & & & $\begin{array}{l}100 \mathrm{~g} \\
\mathrm{ep}\end{array}$ & $\begin{array}{l}250 \mathrm{~g} \\
\mathrm{ep}\end{array}$ & $\begin{array}{c}100 \mathrm{~g} \\
\mathrm{ep}\end{array}$ & $500 \mathrm{~g}$ ep \\
\hline \multirow{5}{*}{$\begin{array}{c}\text { Nshikazi } \\
\text { Bukavu (South } \\
\text { Kivu) }\end{array}$} & Raw stage 1 & 375.66 & 31.30 & 7.83 & 19.57 & 4.47 & 22.36 \\
\hline & Raw stage 3 & 551.92 & 45.99 & 11.50 & 28.75 & 6.57 & 32.85 \\
\hline & Raw stage 5 & 305.95 & 25.50 & 6.37 & 15.93 & 3.64 & 18.21 \\
\hline & Raw stage 7 & 577.74 & 48.15 & 12.04 & 30.09 & 6.88 & 34.39 \\
\hline & Boiled no peel & 265.92 & 22.26 & 5.54 & 13.83 & 3.17 & 15.83 \\
\hline \multirow{10}{*}{$\begin{array}{c}\text { Musheba } \\
\text { Bukavu (South } \\
\text { Kivu) }\end{array}$} & Boiled in-peel & 340.94 & 28.41 & 7.10 & 17.76 & 4.06 & 20.29 \\
\hline & Raw stage 1 & 316.05 & 26.34 & 6.58 & 16.46 & 3.76 & 18.81 \\
\hline & Raw stage 3 & 1022.37 & 85.20 & 21.30 & 53.25 & 12.17 & 60.86 \\
\hline & Raw stage 5 & 799.12 & 66.59 & 16.65 & 41.62 & 9.51 & 47.57 \\
\hline & Raw stage 7 & 500.13 & 41.68 & 10.42 & 26.05 & 5.95 & 29.77 \\
\hline & Boiled no peel & 580.16 & 48.35 & 12.09 & 30.22 & 6.91 & 34.53 \\
\hline & Boiled in-peel & 580.43 & 48.37 & 12.09 & 30.23 & 6.91 & 34.55 \\
\hline & Deep fried palm oil & 6316.51 & 526.38 & 131.59 & 328.98 & 78.20 & 375.98 \\
\hline & Deep fried refined oil & 2297.77 & 191.48 & 47.87 & 119.68 & 27.35 & 136.77 \\
\hline & Musheba flour & 1087.59 & 90.63 & 22.66 & 56.65 & 12.95 & 64.74 \\
\hline \multirow{8}{*}{$\begin{array}{c}\text { Musilongo } \\
\text { Beni (North } \\
\text { Kivu) }\end{array}$} & Raw stage 2 & 1210.37 & 100.86 & 25.22 & 63.04 & 14.41 & 72.05 \\
\hline & Raw stage 3 & 1515.87 & 126.32 & 31.58 & 78.95 & 18.05 & 90.23 \\
\hline & Raw stage 5 & 1051.96 & 87.66 & 21.92 & 54.79 & 12.52 & 62.62 \\
\hline & Raw stage 7 & 1161.86 & 96.82 & 24.21 & 60.51 & 13.83 & 69.16 \\
\hline & Boiled no peel & 2083.90 & 173.66 & 43.41 & 108.54 & 4.81 & 124.04 \\
\hline & Boiled in-peel & 1675.57 & 139.63 & 34.91 & 87.27 & 19.95 & 99.74 \\
\hline & Deep fried in palm oil & 5727.64 & 477.30 & 119.33 & 298.31 & 68.19 & 340.93 \\
\hline & Deep fried refined oil & 3058.14 & 254.84 & 63.71 & 159.28 & 36.41 & 182.03 \\
\hline \multirow{7}{*}{$\begin{array}{l}\text { Vulambya Beni } \\
\text { (North Kivu) }\end{array}$} & Musilongo flour & 137.86 & 11.49 & 2.87 & 7.18 & 1.64 & 8.21 \\
\hline & Raw stage 1 & 403.52 & 33.63 & 8.41 & 21.02 & 4.80 & 24.02 \\
\hline & Raw stage 3 & 793.10 & 66.09 & 16.52 & 41.31 & 9.44 & 47.21 \\
\hline & Raw stage 5 & 682.91 & 56.91 & 14.23 & 35.57 & 8.13 & 40.65 \\
\hline & Raw stage 7 & 648.27 & 54.02 & 13.51 & 33.76 & 7.72 & 38.59 \\
\hline & Boiled no peel & 383.91 & 31.99 & 8.00 & 20.00 & 4.15 & 30.77 \\
\hline & Boiled in-peel & 516.94 & 43.08 & 10.77 & 26.92 & 6.15 & 36.11 \\
\hline
\end{tabular}

Values are means of three independent manipulations; $\mathrm{DRC}=$ Democratic Republic of Congo; ep=Edible portion.

Children between 1-5years and women of reproductive age constitute the most nutritionally vulnerable population groups (McLaren \& Frigg, 2001). According to FAO/WHO (2002), a child aged 1-5years and a non-pregnant/non-lactating woman of reproductive age needs between $400 \mu \mathrm{g}$ and $700 \mu \mathrm{g}$ of vitamin $\mathrm{A}$ in a day 
respectively. Results from Ekesa et al. (2012), indicate the cultivars tested in this study are normally processed into various forms ranging from boiling, frying, roasting to grinding into flour before consumption in Eastern DRC. In addition, consumption of $250 \mathrm{gfw}$ (approximately 2 fingers) of cooked Musa fruit by a child below five years and $500 \mathrm{~g}$ (approximately 3 fingers) by a woman of reproductive age in Banana growing and consuming regions of Africa is considered to be within normal consumption levels (Rodriguez-Amaya, 1997).

Based on normal consumption levels (Rodriguez-Amaya, 1997), daily consumption of boiled 'Vulambya' and 'Nshikazi' would meet $14 \%-27 \%$ of the daily vitamin A RDIs of a child 12-59 months and a woman of reproductive age. The boiled plantains would meet at least $30 \%$ of the daily vitamin A RDIs of the same child and woman. Just $100 \mathrm{~g}$ of the plantains whether deep fried in local palm oil or ordinary cooking oil would meet more than $100 \%$ of daily vitamin A RDIs for a child $12-59$ months and a woman of reproductive age (Table 5). Nutrients compete with each other for absorption, and will also enhance/reduce absorption by the body. In addition, health status of an individual will definitely affect the amount of nutrient eventually available for utilisation by the body. Despite this, the contribution to the daily vitamin A RDIs in this study are based on the assumption that bioavailability of these pVACs is optimal.

\section{Conclusions}

This study confirms findings by Englberger et al. (2006a, 2006b), Davey et al. (2009a, 2009b) and Ngoh-Newilah et al. (2009), that darker (orange/red/dark yellow) pulped Musa cultivars generally have significantly higher values of carotenoids as compared to lighter (ivory/cream/light yellow) pulped Musa cultivars.

Our HPLC results show that during post-harvest maturation (ripening) of 'Musheba', 'Musilongo', Vulambya' and 'Nshikazi', there is a slight increase in pVACs contents, with the highest levels observed when the fruit starts to ripen at stage 3. The popular Musa cultivars in Eastern DRC examined here have nutritional values of between 46 RAE and $87.7 \mathrm{RAE} \mu \mathrm{g} / 100 \mathrm{gfw}$ when raw at ripening stage 1 to 7 . Boiling does not result in a significant loss or breakdown of pVACs in the plantain varieties, but when the East African Highland bananas are boiled, losses of up to $50 \%$ were observed.

Based on normal consumption levels (Rodriguez-Amaya, 1997), daily consumption of boiled 'Vulambya' and 'Nshikazi' would meet $14 \%-27 \%$ of the daily Vitamin A RDIs of a child $12-59$ months and a woman of reproductive age. Boiled 'Musilongo' and 'Musheba' would meet between $30 \%$ and $108 \%$ of the daily vitamin A RDIs of the same child and woman. Just $100 \mathrm{gfw}$ of 'Musilongo'/'Musheba' deep fried in vegetable oil would meet more than $100 \%$ of daily vitamin A RDIs for a child $12-59$ months, and a woman of reproductive age.

With appropriate post-harvest practices (storage, processing and cooking), bananas and plantains popular among smallholder households of eastern DRC have potential in contributing substantially to the vitamin A requirements of the vulnerable population groups.

\section{Recommendations}

Our results here suggest that to maximize pVACs intake from Musa foods, communities should be encouraged and supported in developing best-practices on appropriate post-harvest handling, processing/cooking and diversification of diets based on bananas and plantains.

In addition, since bioaccessibility and bioavailability studies of the Musa products/dishes are in the pipeline, conclusions from these studies are needed to help determine the actual contribution of the Musa cultivars to the vitamin A requirements of the vulnerable groups.

This study took into consideration only the two popular plantains and two popular cooking bananas (AAA-EAHB), and only evaluated pVACs. There are over 20 Musa cultivars in Eastern DRC (Dowiya et al., 2009) and research has indicated that there is always nutrient-nutrient interaction i.e. an increase in dietary fat content increases carotene absorption, and protein deficiency decreases intestinal absorption of vitamin A (Caballero, 1988). Therefore there is a need to carry out an evaluation of more local cultivars and take into consideration the nutrition profile of both macronutrients and micronutrients. In addition, A number of Pacific Island Musa cultivars have been proven to be very superior in carotenoids (Ploetz, Kepler, Daniells, \& Nelson, 2007). Their agronomic adaptation within Eastern Africa should be tested and nutrition profile of those found to have high yields evaluated. They could be then be promoted and incorporated within existing farming systems for crop and dietary diversity.

\section{Acknowledgements}

Harvest Plus through Bioversity International is acknowledged for providing the necessary funding to carry out 
the laboratory analysis. Mr. Charles Lwanga of North Kivu (Butembo-DRC) and Mr. Jules Ntamwira of South Kivu (Bukavu-DRC) are also thanked for ensuring that the Musa fruit samples got to Kampala in good time and condition. IITA and CIP personnel at Namulonge laboratory (Kampala, Uganda) are appreciated for their help during sample preparation and processing. Sincere gratitude goes to Ms. Ifigeneia Mellidou of the laboratory of fruit breeding and biotechnology, Katholieke University of Leuven (Belgium) for her assistance and guidance during the analysis process. Mr Vincent Johnson, of Bioversity International, Montpellier, France is acknowledged for his support in editing this paper.

\section{References}

Amankwah, E. A., Ayim, I., Dzisi, K. A., \& Barimah, j. (2011). Nutritional content and functional properties of french horn, false horn and FHIA-21. American Journal of Food Technology., 6(4), 322-328. http://dx.doi.org/10.3923/ajft.2011.322.328

Ayewole Olusola, B., \& Asagbra, Y. (2003). Improving traditional cassava processing for nutrition enhancement. $2^{\text {nd }}$ International workshop: Food-based approaches for a healthy nutrition. Ougadougou.

Azevedo-Meleiro, C. H., \& Rodriguez-Amaya, D. B. (2004). Confirmation of the identity of the carotenoids of tropical fruits by HPLCDAD and HPLC-MS. Journal of Food Composition and Analysis, 17, 385-396. http://dx.doi.org/10.1016/j.jfca.2004.02.004

Azizah, A. H., Wee, K. C., Azizah, O., \& Azizah, M. (2009). Effect of boiling and stir frying on total phenolics, carotenoids and radical scavenging activity of pumpkin (Cucurbita moschato). International Food Research Journal, 16, 45-51. Retrieved from http://ifrj.upm.edu.my/16\%20\%281\%29\%202009/06\%20IFRJ-2008-123\%20Azizah\%20Malaysia\%20FIN AL.pdf

Bengtsson, A., Namutebi, A., Larsson Alminger, M., \& Svanberg, U. (2008). Effects of various traditional processing methods on the all-trans- $\beta$-carotene content of orange-fleshed sweet potato. Journal of food composition and analysis, 21(2), 134-143. http://dx.doi.org/10.1016/j.jfca.2007.09.006

Booth, S. L., Johns, T., \& Kuhunlein, H. V. (1992). Natural food Sources of vitamin A and Provitamin A. Food and Nutrition Bulletin, 14(1), 6-19

Caballero, B. (1988). Nutrition implications of dietary interactions: A review. Food and Nutrition Bulletin. United Nations University, 10(2).

Dadzie, B. K., \& Orchard, J. E. (1997). Routine Post-harvest Screening of Banana/Plantain Hybrids: Criteria and Methods. INIBAP Technical Guidelines 2. International Plant Genetic Resources Institute, Rome, Italy; International Network for the improvement of banana and plantain, Montpellier, France; ACPEU Technical Centre for Agricultural and Rural Cooperation, Wageningen, The Netherlands, pp 63.

Davey, M. W., Van den Bergh, I., Markham, R., Swennen, R., \& Keulemans, J. (2009a). Genetic variability in Musa fruit provitamin A carotenoids, lutein and mineral micronutrient contents. Food Chemistry, 115, 806-813. http://dx.doi.org/10.1016/j.foodchem.2008.12.088

Davey, M. W., Saeys, W., Hof, E., Ramon, H., Swennen, R. L., \& Keulemans, J. (2009b). Application of visible and near-infrared reflectance spectroscopy (Vis/Nirs) to determine carotenoid contents in banana (Musa Spp.) fruit pulp. Journal of Agriculture and Food Chemistry, 57, 1742-1751. http://dx.doi.org/10.1021/jf803137d

Davey, M. W., Stals, E., Ngoh-Newilah, G., Tomekpe, K., Lusty, C., Markham, R., ... Keulemans, J. (2007). Sampling strategies and variability in fruit pulp micronutrient contents of west and central African bananas and plantains (Musa species). Journal of Agricultural and Food Chemistry, 55(7), 2633-44. http://dx.doi.org/10.1021/jf0631191

Davey, M. W., Kuelemans, J., \& Swennen, R. (2006). Methods of the efficient quantification of fruit provitamin A contents. Journal of Chromatography A, 1136, 176-184. http://dx.doi.org/10.1016/j.chroma.2006.09.077

Dowiya, N. B., Rweyemamu, C. L., \& Maerere, A. P. (2009). Banana (Musa spp. Colla) Cropping Systems, Production Constraints and Cultivar Preferences in Eastern Democratic Republic of Congo. Journal of Animal \& Plant Sciences, 4(2), 341-356.

Ekesa, B. N., Kimiywe, J., Davey, M. W., Dhuique-Mayer, C., Van den Bergh, I., Karamura, D., \& Blomme, G. (2012). Banana and plantain (Musa spp.) cultivar preference, local processing/cooking techniques and consumption patterns in Eastern Democratic Republic of Congo. International Journal of Agriculture 
science, 4(8), 312-319.

Englberger, L., Ron, B. H. W., Wills, B. B., Dufficy, F., Daniells, J. W., \& Coyne, T. (2006a). Carotenoid content and flesh color of selected banana cultivars in Australia. Food and Nutrition Bulletin, 27(4). The United Nations University.

Englberger, L., Schierle, J., Aalbersberg, W., Hofmann, P., Humphries, J., Huang, A., ... Fitzgerald, M. H. (2006b). Carotenoid and Vitamin Content of Karat And Other Micronesian Banana Cultivars. International Journal of Food Sciences and Nutrition, 57(5/6), 399-418. http://dx.doi.org/10.1080/09637480600872010

Englberger, L., Schierle, J., Marks, G. C., \& Fitzgerald, M. H. (2003a). Micronesian banana, taro, and other foods: newly recognized sources of provitamin A and other carotenoids Journal of Food Composition and Analysis, 16, 3-19. http://dx.doi.org/10.1016/S0889-1575(02)00133-3

Englberger, L., Aalbersberg, W., Ravi, P., Bonnin, E., Marks, G. C., Fitzgerald, M. H., \& Elymore, J. (2003b). Further analyses on Micronesian banana, taro, breadfruit and other foods for provitamin A carotenoids and minerals. Journal of Food Composition and Analysis, 16(220), 219-236. http://dx.doi.org/10.1016/S0889-1575(02)00171-0

FAO/WHO. (2002). Human vitamin and mineral requirements. Report of a joint FAO/WHO expert consultation, Bangkok, Thailand. Rome: FAO and WHO.

Fraser, P. D., \& Bramley, P. M. (2004). The biosynthesis and nutritional uses of carotenoids. Prog. Lipd Res., 43(3), 228-265. http://dx.doi.org/10.1016/j.plipres.2003.10.002

Howe, J. A., \& Tanumihardjo, S. A. (2006). Carotenoid-biofortified maize maintains adequate vitamin A status in Mongolian gerbils. The Journal of Nutrition, 136, 2562-2567.

McLaren, D. S., \& Frigg, M. (2001). Sight and Life manual on vitamin A deficiency disorders (VADD) (2nd ed.). Task Force Sight and Life, Basel, Switzerland. Retrieved from http://www.who.int/ncd/vision2020_actionplan/documents/00allman.pdf

Ngoh-Newilah, G., Lusty, C., Van den Bergh, I., Akyeampong, E., Davey, M. W., \& Tomekpe, K. (2007). Evaluating Bananas and Plantains Grown in Cameroon as a Potential Source of Carotenoids. African Crop Science Conference Proceedings, 8, 1773-1778.

Ngoh-Newilah, G., Lusty, C., Van den Bergh, I., Akyeampong, E., Davey, M. W., \& Tomekpe, K (2008). Evaluating Bananas and Plantains Grown in Cameroon as a Potential Source of Carotenoids. Food: Global Science Books.

Ngoh-Newilah, G., Dhuique-Mayer, C., Rojas-Gonzalez, J., Tomekpe, K., Fokou, E., \& Etoa, F. X. (2009). Carotenoid content during ripening of banana hybrids and cultivars grown in Cameroon. Fruits., 64, 197-206. http://dx.doi.org/10.1051/fruits/2009015

Ploetz, R. C., Kepler A. K, Daniells, J., \& Nelson, S. C. (2007). Banana and plantain-an overview with emphasis on Pacific island cultivars, ver. 1. In Elevitch, C. R. (Eds.). Species Profiles for Pacific Island Agroforestry. Permanent Agriculture Resources (PAR), Hōlualoa, Hawai'i. Retrieved from http://www.traditionaltree.org

Rodrigues-Amaya, D. B., \& Kimura, M. (2004). HarvestPlus Handbook for carotenoids analyses. Harvestplus Handbook for Carotenoid Analysis. HarvestPlus Technical Monograph 2. Washington, DC and Cali: International Food Policy Research Institute (IFPRI) and International Center for Tropical Agriculture (CIAT). pp. 5-6.

Rodriguez-Amaya, Delia, B. (1997). Carotenoids and Food Preparation: The Retention of Provitamin A Carotenoids in Prepared, Processed, and Stored Foods. Departamento de Ciências de Alimentos Faculdade de Engenharia de Alimentos Universidade Estadual de Campinas C.P. 6121, 13083-970 Campinas, SP., Brazil. Retrieved from http://pdf.usaid.gov/pdf_docs/PNACB907.pdf

Rojas-Gonzalez J. A., Avallone, S., Brat, P., Trystram, G., \& Bohuon, P. (2006). Effect of deep-fat frying on ascorbic acid, carotenoids and potassium contents of plantain cylinders. International Journal of Food Sciences and Nutrition, 57(1-2), 123-136. http://dx.doi.org/10.1080/09637480600658393

Ruel, M. T., \& Howarth, B. E. (2004). Home preparation, processing and conservation techniques to increase the micronutrient content of foods: Food Modification and Impact on Nutrition. International Food Policy Research Institute. Food and Agricultural Sciences, Engineering and Technology Resources. Sample Chapters. Washington DC. Retrieved from http://www.eolss.net/eolsssamplechapters/c10/e5-01a-07-06/E5-01A-07-06-TXT-05.aspx 
Schieber, A., \& Carle, R. (2005). Occurance of of carotenoid cis-isomers in food: Technological, analytical, and nutrition implications. Trends in food science and technology, 16(9), 416-422. http://dx.doi.org/10.1016/j.tifs.2005.03.018

SCN. (2010). Vitamin A deficiency; Regional trends: Progress in nutrition. Sixth Report on the World Nutrition Situation, Geneva. United Nations System Standing committee on Nutrition. United Nations System. 2, 8-22. Retrieved from http://www.unscn.org/files/Publications/RWNS6/report/SCN_report.pdf.

Stover, R. H., \&Simmonds, N. W. (1987). Bananas. Bananas. (3rd ed.). Tropical Agricultural Series. Longman, Essex, UK.

Trumbo, P. R., Yates, A. A., Schlicker-Renfro, S., \& Suitor, C. (2003). Dietary reference intakes: Revised nutritional equivalents for folate, vitamin $\mathrm{E}$ and provitamin A carotenoids. Journal of food composition and analysis, 16(3), 379-382. http://dx.doi.org/10.1016/S0889-1575(03)00025-5

Van den Bergh, I., \& Vezina, A. (2012). Vitamin A In Musapedia, the banana knowledge compendium. Retrieved November 27, 2012, from http://www.promusa.org/tiki-index.php?page=Vitamin+A+in+banana

World Health Organization. (2009). Global prevalence of vitamin A deficiency (1995-2005). WHO global database on vitamin A deficiency Geneva, World Health Organization, 2009. Retrieved from http://www.who.int/vmnis/vitamina/prevalence/en/ 